\title{
EFFECT OF DETERGENT - POLLUTED WATER ON THE HEALTH OF TOMATO PLANTS.
}

Hassouna, M. G.*; S. S. Aboshosha*; S. A. Soliman ${ }^{\star \star}$ and M. S. Al-Dahmashi*

* Department of Plant Pathology, Faculty of Agriculture, Alexandria University, Alexandria, Egypt.

** Department of Pesticides, Faculty of Agriculture, Alexandria University, Alexandria, Egypt.

\section{ABSTRACT}

The effect of detergent-polluted water (DPW) at the concentrations 0.52, 1.05, 2.10 , and $4.20 \mathrm{~g} \mathrm{l}^{-1}$ (the recommended) on the growth of tomato plants was assayed. Seed germination and seedling length were increased with the two lower concentrations 0.52 and $1.05 \mathrm{~g} \mathrm{l}^{-1}$, and decreased with 2.10 and $4.20 \mathrm{~g} \mathrm{l}^{-1}$ (DPW) concentration. The growing seedlings and plants were dwarfed, malformed and brownish with the increase of the detergent concentration. The two higher concentrations reduced the dry weights of root by 25 and $81 \%$ and the shoot by 11 $57 \%$. The number of surviving plants, and chlorophyll contents were also decreased . Carotene at 5 -leaves stage was decreased by 13 and $25 \%$, and slightly increased at the 8-leaves stage with the $0.52 \mathrm{~g} \mathrm{l}^{-1}$ (DPW) concentration and fluctuated around the control treatment at the flowering stage. The total soluble proteins of roots and shoots were clearly increased with the two lower concentrations, and sharply decreased by 24 and $50 \%$ with the 2.10 and $4.20 \mathrm{~g} \mathrm{l}^{-1}$ concentrations, respectively. The protein pattern showed changes, (as compared with the control plant proteins), where new and missed proteins bands were detected, at each detergent concentration. All these changes are related to the changes observed on the growth and health of tomato plants.

Keywords: Detergent; Tomato; Growth; Chlorophyll; Carotenes; Protein, water pollution.

\section{INTRODUCTION}

Water Pollution due synthetic detergents has continuously increased during the last few decades. The Worldwide production of surfactants amounted to 17-19 million metric tons (Deleu and Paquot, 2004). In 1996, the Egyptian market consumed 306,000 tons of detergents and soap (Ibrahim, 1996), while Yemeni market consumed 53000 tons of powder detergents in the year 2000 (Statistical Year-Book, 2000, Republic of Yemen). The harmful effects of detergents in natural waters may result from their general impact on the biogeochemical cycle of other pollutants and biogenic elements. Furthermore, solubility of many toxic substances is increased in the presence of detergents, (i.e., metals, mineral oil components and other hydrocarbons), (Kozarac et al., 1975; Volkering et al., 1998).

The existence of surfactants in water even under the toxic level, causes the break-up of the chlorophyll-protein complex and death of the cell by damaging the membranes of aquatic plants (Helleston, 1986). However, Jensen (1999) mentioned the following effects on plants after Linear Alkylbenzene sulfonate (LAS) exposure: destruction of root-cell-membrane, changes in membrane permeability, changes in fine structures, and effects on physiological processes, such as photosynthesis. 
Hassouna, M. G. et al.

Thousands of Villages, in the developing and underdeveloped countries are deprived of clean water facilities. Reusing the detergent polluted water in irrigation, was accompanied by crop and soil deterioration. (Statistical Year - Book 2000, Republic of Yemen).

The aim of this study was to follow the effect of detergent-polluted water (DPW), (using commercial powder detergent as a representative of most detergents), on tomato seed germination, seedlings growth, dry mass of growing plants, survival, chlorophyll and carotene contents, and total soluble proteins.

\section{MATERIALS AND METHODS}

\section{In vitro Experiments:}

Petri dishes $(15 \mathrm{~cm})$ containing filter papers were saturated with one of the following detergent concentrations: $0.0,0.52,1.05,2.10$ and $4.20 \mathrm{~g} \mathrm{l}^{-1}(4$ dishes per concentration). Each dish was seeded with 100 seeds of tomato. (lycopersicon esculentum var castle rock). Every dish was re-saturated with 5 $\mathrm{ml}$ of the same concentration on the fourth day after seeding. The average percentages of germinated seeds and seedlings length were measured after 7 days. Also, the visual symptoms of the growing seedlings were recorded and photographed.

\section{In vivo Experiments:}

One hundred pots (20 cm in diameter), was filled with $3.5 \mathrm{~kg}$ sandy soil were used in these experiments. Each 20 pots was treated with one of the five detergent concentrations mentioned above. All pots were randomly distributed and 20 seeds were sown at a depth of $0.5-1 \mathrm{~cm}$ in each pot. All pots were irrigated with tap water until full saturation and then irrigated with $200 \mathrm{ml}$ tap water every two days for 10 days. The 10-days old seedlings were thinned to 3 seedlings per pot. Then, each pot was irrigated weekly with $400 \mathrm{ml}$ of each of the detergent concentration throughout the course of the experiment.

\subsection{Growth Measurements and Visual Symptoms:}

The plants were carefully freed from soil kept with their intact roots, washed with tap water, and rinsed three times with distilled water. The percentage of surviving plants was recorded for four weeks.

The visual disease symptoms of the growing plants were recorded and photographed. Roots and shoots dry mass were determined.

\subsection{Chlorophyll and Carotene Contents:}

Discs from tomato leaves $(250 \mathrm{mg})$ were homogenized in $20 \mathrm{ml}$ acetone $(80 \%)$ until leaves debris became colorless. For chlorophylls determination, the homogenate was centrifuged at $10,000 \mathrm{rpm}$ for 10 minutes. The absorbance was measured at 645 and $667 \mathrm{~nm}$ against a blank, according to Arnon (1949). For carotene, the resulting homogenate was centrifuged for $10 \mathrm{~min}$ at $4300 \mathrm{rpm}$ and the absorbance was measured at $445 \mathrm{~nm}$ against a blank of acetone $80 \%$ according to Mayfield et al., 1986.

\subsection{Determination of Total Soluble Proteins:}

Total proteins of roots and shoots were extracted according to Abo ElSaad and Wu (1995), and were determined according to Lowry et al (1951). 


\subsection{Sodium Dodecyl Sulphate poly-acrylamide Gel Electrophores (SDS-} PAGE) of Total Proteins:

One-dimensional SDS-PAGE was performed with mini-protean apparatus (Bio-Rad) using the method of Laemmli (1970). The protein molecular marker used was low-range protein. The resulting gels were photographed and the photos were used to determine the molecular weights using Totallab Image Analysis Software version 1.11 (Nonlinear Dynamics Company, 1998).

\section{EXPERIMENTAL RESULTS}

\section{Tomato Seed Germination:}

Figure 1 illustrates that the $\left(1.05 \mathrm{~g} \mathrm{l}^{-1}\right)$ concentration slightly enhanced seed germination by $9 \%$, while the highest concentration $\left(4.20 \mathrm{~g} \mathrm{I}^{-1}\right)$ significantly suppressed germination by $37 \%$, compared with the control.

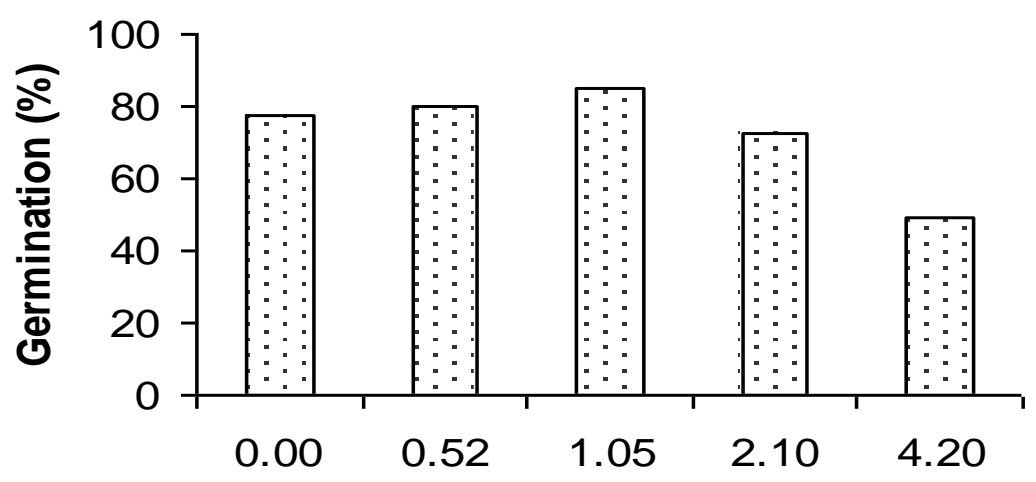

Detergent concentration ( $g / L)$

Fig. 1. Germination Percentage of tomato seeds treated with different detergent concentrations.

\section{Seedling Length and Malformation:}

The growing seedlings were dwarfed, malformed with the increase of the detergent concentration (Fig. 2). The length of 7-days old tomato seedlings was increased by $39 \%$ when treated with the lowest concentration $\left(0.52 \mathrm{~g} \mathrm{l}^{-1}\right)$ (Fig. 3), while the two higher concentrations (2.10 and $\left.4.20 \mathrm{~g} \mathrm{l}^{-1}\right)$ significantly suppressed seedling length by 42 and $76 \%$ respectively.

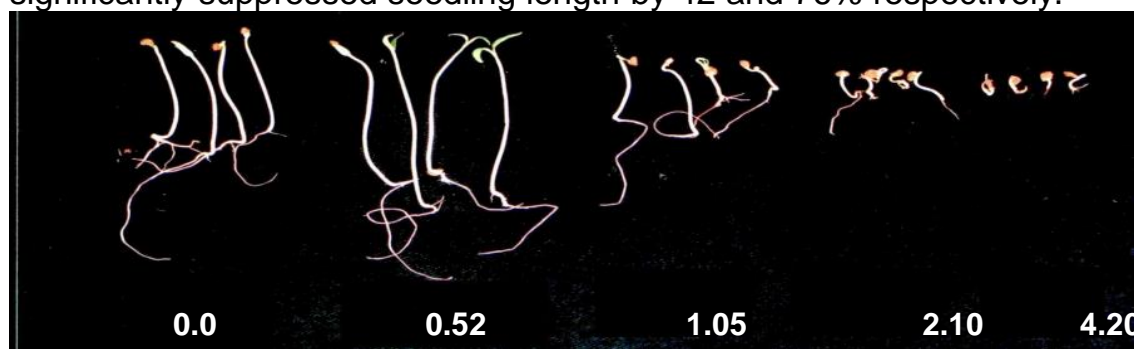

Fig. 2: Effect of different detergent concentrations $\left(\mathrm{g} \mathrm{l}^{-1}\right)$ on the growing 7-days old tomato seedlings. 
Hassouna, M. G. et al.

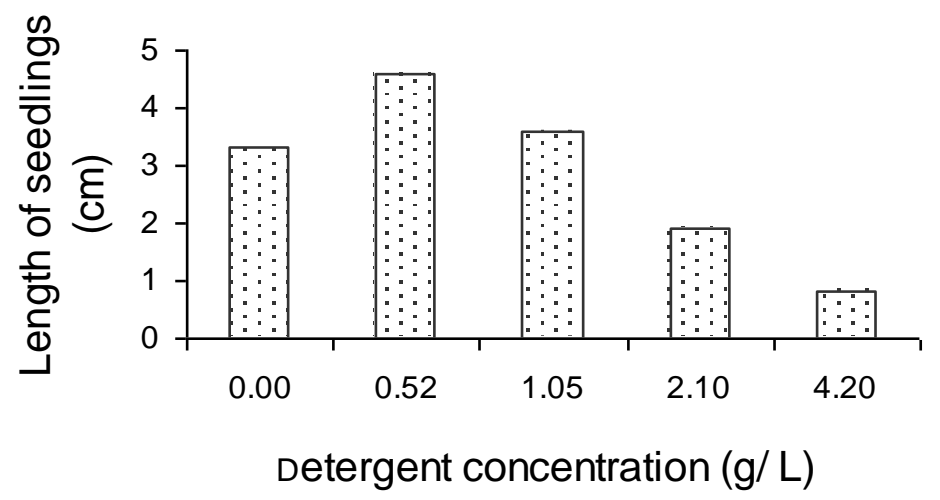

Fig. 3. Length of 7-days old tomato seedlings treated with different detergent concentrations.

\section{Visual Symptoms on the Growing Tomato Plants:}

Tomato plants irrigated with the higher concentrations showed slight stunting. Roots were less branched and slimmer than roots of control plants (Fig. 4). Tomato vegetative growth was slightly increased with the lower concentrations and was reduced at higher concentrations $\left(4.20 \mathrm{~g} \mathrm{l}^{-1}\right)$

3.1. Dry Mass of Tomato Roots and Shoots:

(Fig. 5) shows the dry mass of tomato roots and shoots - at the three growth stages. (5-leaves-, 8-leaves-, and flowering- stage). The dry mass were decreased when the plants were irrigated with the two higher concentrations (2.10 and $\left.4.20 \mathrm{~g} \mathrm{l}^{-1}\right)$, while the lowest concentrations $0.52 \mathrm{~g} / \mathrm{L}$ increased the dry mass of the roots and shoots.

\subsection{Percentage of Survived Tomato Plants:}

There was no drastic decrease in number of surviving plants, except for the recommended concentration $\left(4.20 \mathrm{~g} \mathrm{I}^{-1}\right)$, which killed $55 \%$ of the plants within 3 weeks (Fig. 6). The plants did not show the capability of recovery, or restoring their vitality or adapt itself to the detergent.

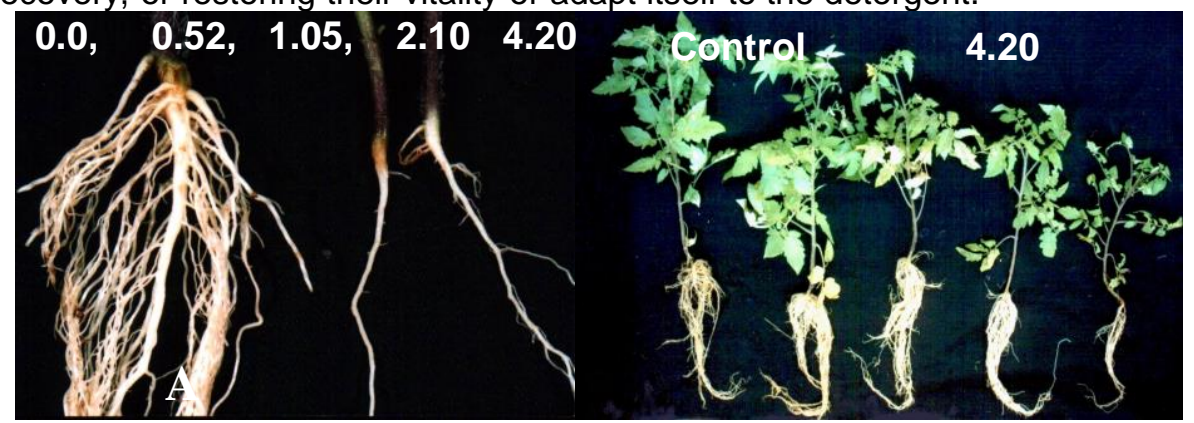

Fig. 4: The effect of DPW on the growth of tomato plants, left) the growth of plants under different detergent concentrations $\left(\mathrm{g} \mathrm{l}^{-1}\right)$, right) comparison between root system of control plants and the root system at the highest concentration. 

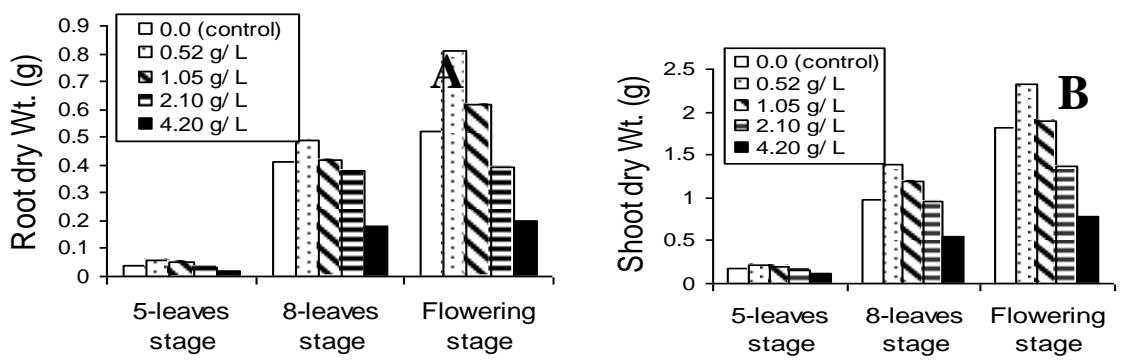

Fig. 5: The effect of different detergent concentrations on: A) root dry weight; and B) shoot dry weight.

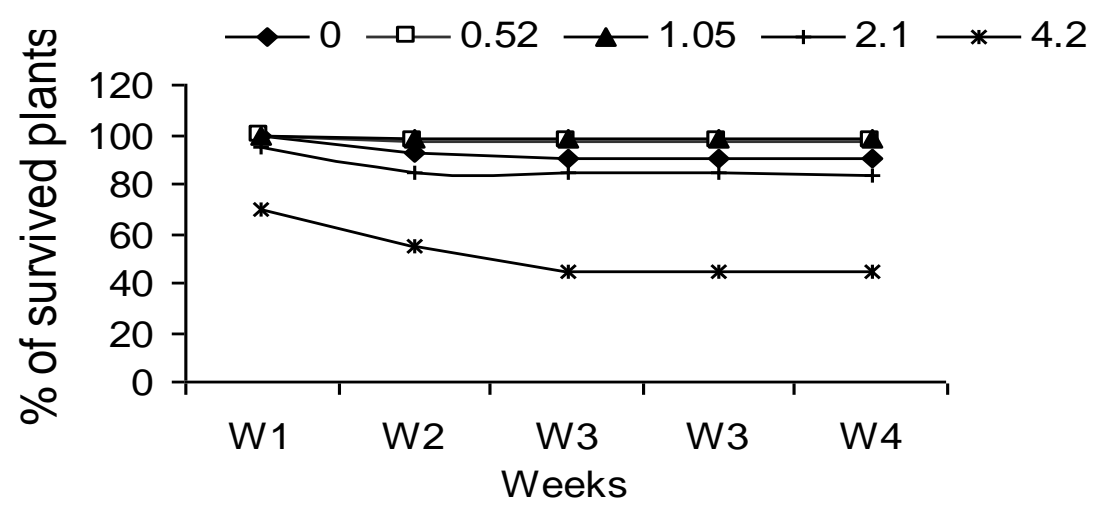

Fig. 6: Percentage of survived tomato plants irrigated weekly with different detergent concentrations $\left(\mathrm{g} \mathrm{l}^{-1}\right)$ for four weeks (pot experiment).

\subsection{Chlorophyll and Carotene Contents:}

Chlorophylls a, b and total chlorophyll in tomato leaves are shown in Fig 7. At 5- and 8-leaves stages, the three higher concentrations (1.05, 2.10 and $4.20 \mathrm{~g} \mathrm{l}^{-1}$ ) reduced chlorophyll $\mathrm{a}$, chlorophyll $\mathrm{b}$ and the total chlorophylls. The reduction in chlorophyll contents - with the two higher concentrations (2.10 and $\left.4.20 \mathrm{~g} \mathrm{l}^{-1}\right)$ - was significant at the flowering stage. Compared with the control, carotene content (Fig 8), at the 5-leaves stage was decreased with all detergent concentrations. At 8-leaves stage, $0.52 \mathrm{~g} \mathrm{l}^{-1}$ concentration induced the carotene formation by $10 \%$. At the flowering stage, the carotene content fluctuated around the control value. 

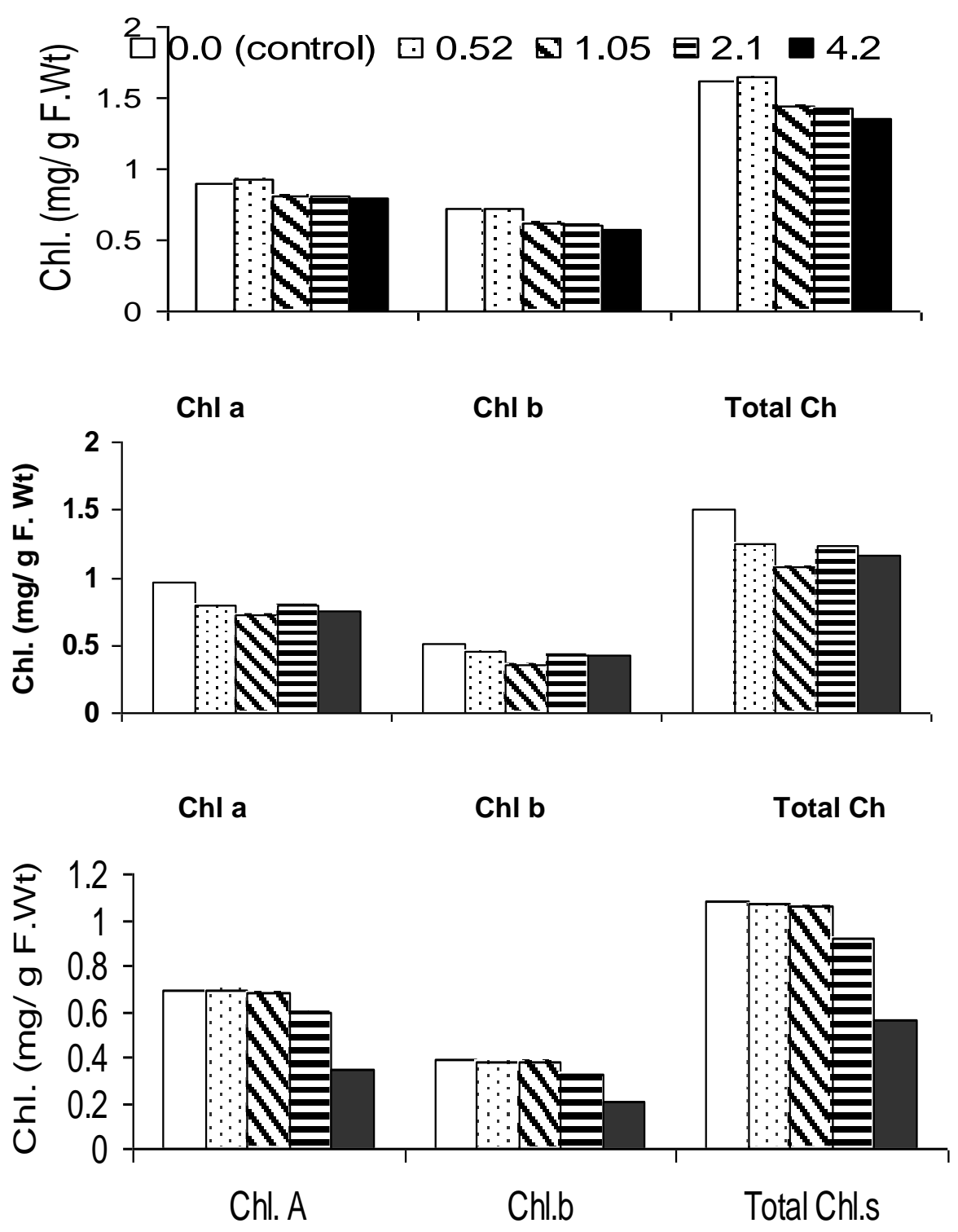

Fig. 7: Chlorophyll a, b and total chlorophyll ( $\mathrm{mg} \mathrm{g}^{-1}$ fresh weight) in leaves of tomato plants at: A) 5-leaves stage(top); B) 8-leaves stage, and $C$ ) at flowering stage of growth, weekly irrigated with different detergent concentrations $\left(\mathrm{g} \mathrm{l}^{-1}\right)$ (pot experiment). 
$\square 0.0$ (control) $\square 0.52 \square 1.05 \boxminus 2.1 \square 4.2$

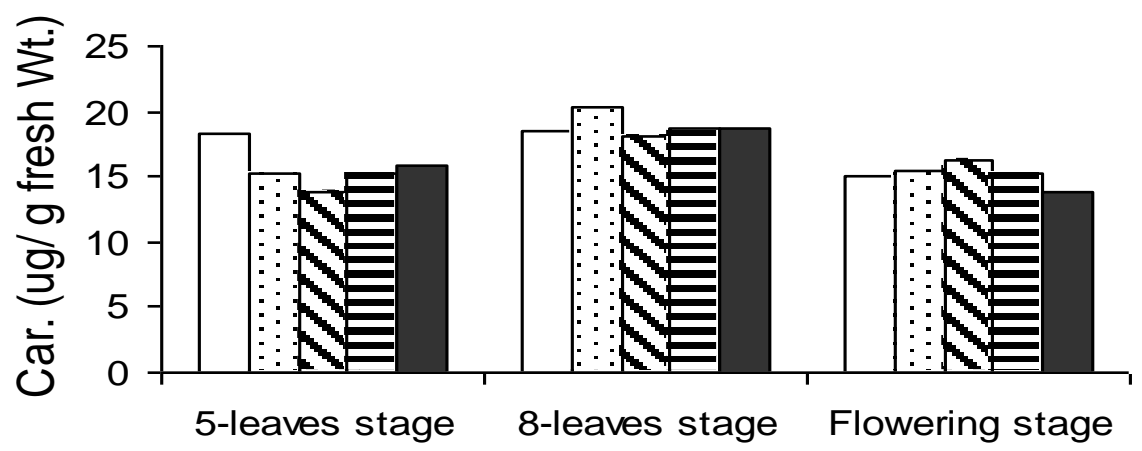

Fig. 8: Carotenes ( $\mu \mathrm{g} \mathrm{g} \mathrm{g}^{-1}$ fresh weight) in leaves of tomato plants, weekly irrigated with different detergent concentrations $\left(\mathrm{g} \mathrm{l}^{-1}\right)$ of (pot experiment).

\subsection{Total -Soluble Proteins of Tomato Roots and Shoots:}

The total soluble proteins of roots and shoots decreased with the two higher concentrations, 2.10 and $4.20 \mathrm{~g} \mathrm{l}^{-1}$ (Fig. 9), and were significantly increased with the two lower concentrations 0.52 and $1.05 \mathrm{~g} \mathrm{l}^{-1}$.

\subsection{SDS-PAGE of Total Soluble Proteins:}

Figure 10 shows the protein pattern of 5 -leaved tomato roots. There were real differences in the number and protein patterns of tomato roots and shoots. With the roots of tomato plants irrigated with $0.52 \mathrm{~g} \mathrm{l}^{-1}$, two new protein bands were formed and 5 protein band disappeared. With $1.05 \mathrm{~g} \mathrm{I}^{-1}$, a new protein band was found and 3 protein bands were missing. With $2.10 \mathrm{~g} \mathrm{l}$ 1,5 new protein bands were found. With $4.20 \mathrm{~g} \mathrm{l}^{-1}$, a new protein band was found and 3 protein bands were missing. In tomato shoot protein pattern, compared with control, a new protein band was found with $0.52 \mathrm{~g} \mathrm{l}^{-1}$. With the $1.05 \mathrm{~g} \mathrm{l}^{-1}$, two protein bands were missing. With $2.10 \mathrm{~g} \mathrm{l}^{-1}$ or $4.20 \mathrm{~g} \mathrm{l}^{-1}$, one protein band was found and 4 protein bands were missing.

$\square$ roots shoots

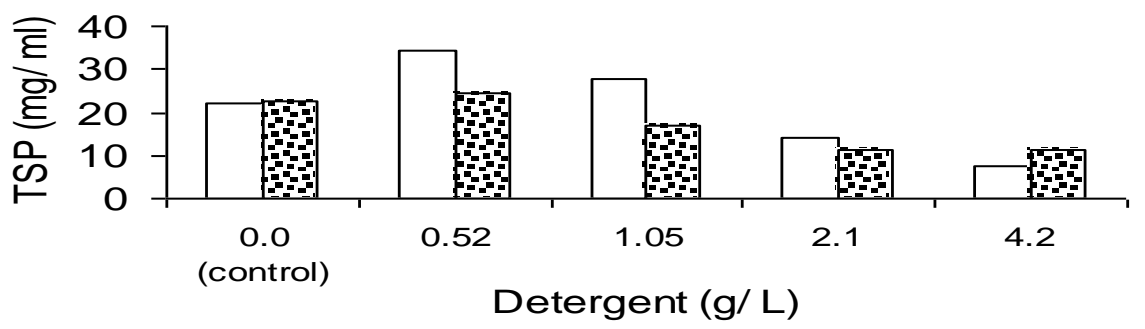

Fig. 9: Total buffer-soluble proteins $\left(\mathrm{mg} \mathrm{ml}^{-1}\right)$ of the extracts of 5-leaved tomato plants treated with different detergent concentrations (pot experiment). 
Hassouna, M. G. et al.
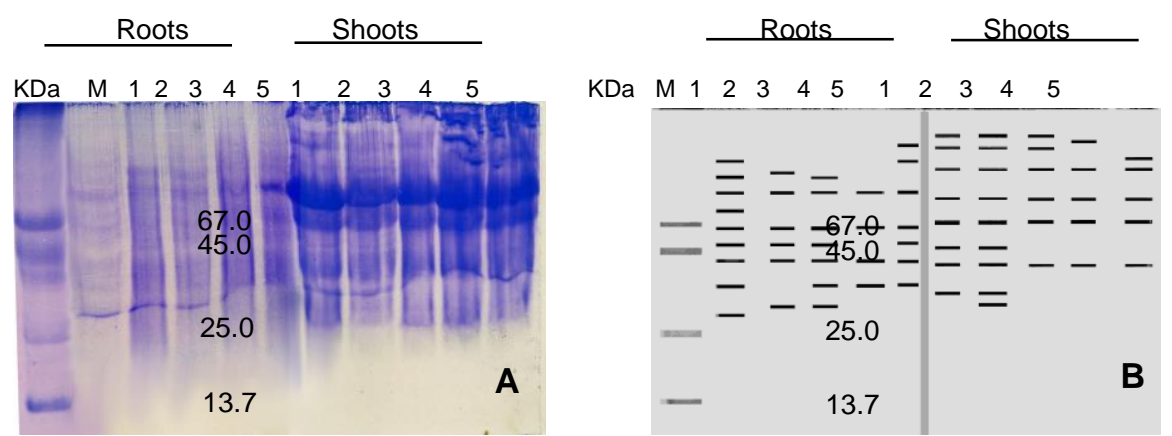

Fig. 10: SDS-PAGE of total soluble proteins isolated from roots and shoots of 5-leaved tomato plants irrigated weekly with different detergent concentrations. Where: $A$ is the original gel and $B$ is the diagram of protein bands of the original gel. Lane $M=$ Lowrange protein marker, Lane $1=$ control, Lane $2=0.52 \mathrm{~g} \mathrm{l}^{-1}$, Lane $3=1.05 \mathrm{~g} \mathrm{l}^{-1}$, Lane $4=2.10 \mathrm{~g} \mathrm{l}^{-1}$, Lane $5=4.20 \mathrm{~g} \mathrm{l}^{-1}$.

\section{DISCUSSION}

Powder detergents are one of the major classes of detergents used in our life, which reach irrigation water and agricultural soil, and may provide a serious stress on the agricultural crops. The study was conducted to investigate the effects of detergent-polluted water (DPW) on the growth of tomato plants. One commercial detergent was chosen, four concentrations: 0.52. $1.05,2.10,4.20 \mathrm{~g} \mathrm{l}^{-1}$, (equal to $0.110,0.220,0.441,0.882 \mathrm{~g} \mathrm{l}^{-1} \mathrm{LAS}$, respectively), and tap water (served as control), were used for irrigation of tomato plants.

The percentage of germinated seeds increased with the two lower concentrations, and decreased by $37 \%$ with $4.20 \mathrm{~g} \mathrm{l}^{-1}$ concentration. These results have the same trend as found by some investigators and differed with others. Lall and Kale (1975) reported that the lower concentration of anionic surf detergent $\left(0.75 \mathrm{~g} \mathrm{l}^{-1}\right)$ promoted the growth of tomato plants, while higher concentrations retarded it. Lian and Shulan (1999) reported the same trend where the low doses of LAS ( Linear Alkylbenzene sulfonate ) stimulated the germination of the seeds of some grassland plants, while the high doses inhibited seed germination. Other investigators reported that LAS concentrations ranging from 5 to $10 \mathrm{mg} \mathrm{l}^{-1}$ had no inhibiting effect on seed germination of some terrestrial plants, while concentrations between10 $4000 \mathrm{mg} \mathrm{l}^{-1}$ had inhibitory effects (e.g. Sharma et al., 1985; Mieure et al., 1990)

The length of tomato seedlings was suppressed with the two higher concentrations used and was promoted with the lowest concentration. Lian and Shulan (1999) reported a significant effect on seedling length with the high LAS concentrations up to $400 \mathrm{mg} \mathrm{l}^{-1}$. Ostroumov and Khoroshilov (1992) found that the "Vilva" liquid detergent completely inhibited the seedlings of Fagopyrum esculentum under the detergent concentration of $0.25 \mathrm{ml} \mathrm{l}^{-1}$.

The growing seedlings were dwarfed, malformed with the increase of the detergent concentration. However, Jensen (1999) reported destruction of 
root-cell-membrane and changes in membrane permeability after LAS exposure. Other investigators found that the increase of surfactant concentrations caused an increase in ethylene production, which was found to correlate with surfactant phytotoxicity (Knoche, 1992; Lownds and Bukovac, 1989, and Seier et al., 1991).

The two higher concentrations reduced root and shoot dry weights at all growth stages, while the lowest concentration increased the root and the shoot dry weights. Similar results were reported by several investigators. On tomato plants, Patruno et al. (1996) found that the presence of Etravon (anionic surfactant) in irrigation water increased the fresh weight by 49 and $97 \%$, on peat and on histosol, respectively. Vavrina et al. (1995) reported that as detergent rate, frequency of application or both increased tomato dry weight and fruit yield decreased. The fertilizing effect of LAS on plant growth and the release of essential elements from the soil matrix in the presence of LAS may be an explanation (Zavala et al. 1975).

There was no drastic decrease in number of survived tomato plants treated with the detergent, except for the recommended concentration (4.20 $\mathrm{g} \mathrm{I}^{-1}$ ), which in 3 weeks, killed more than half of the plants. It was noticed that, the plants that survived for 3 weeks were able to complete their living. Similar trend was showed by Lian and Shulan (1999) working on grassland plants and found real enduring differences between grassland species under LAS stress. However, the negative effect of the different concentrations on the percentage of surviving plants would end in crop reduction. Several authors reported a clear decrease in the yield as a response to detergents stress (Cairns, 1972; Judy et al., 1973; Vavrina et al., 1995; Garland et al., 2000)

The chlorophyll $\mathrm{a}, \mathrm{b}$ and total chlorophyll contents were reduced with the three higher concentrations of the detergent used. Similar trend was reported by Lian and Shulan (1999) where the chlorophyll content of the leaves of four grassland plant species was significantly inhibited with the increase of LAS concentration up to $400 \mathrm{mg} \mathrm{l}^{-1}$.

Also, carotene at the early 5 -leaves stage decreased by $13-25 \%$, and slightly increased at the 8-leaves stage, with the $0.52 \mathrm{~g} \mathrm{l}^{-1}$ concentration, and fluctuated around the control value at the flowering stage. Chiming et al. (1996) worked on normal and golden-leaved Ficus microcarpa plants and found that when the SDS concentration was less than $10^{-5} \%$, more carotenoids were released than chlorophyll. When SDS concentration was between $10^{-5}$ and $10^{-3} \%$, more chlorophyll molecules were released than carotenoids. As the SDS concentration was increased above $10^{-3} \%$, all carotenoids were solubilized. They concluded that in the pigment-protein complexes, carotenoids are more susceptible to SDS than chlorophyll molecules.

The total soluble proteins of roots and shoots were highly increased with the two lower concentrations, and deeply decreased with the two higher concentrations. Similar enhancement effects of the lower detergent concentrations were reported by several investigators. Gadallah (1994) found that the industrial waste waters of detergent and oil factory caused a significant increase in the soluble protein of sunflower shoots and roots. Also 
Seier et al. (1991) working on Phaseolus vulgaris primary leaves, found that the total soluble protein was increased with increasing surfactant concentration in the range of $0.01-0.5 \%$.

The patterns of total soluble proteins of roots and shoots were assayed by SDS-PAGE. The soluble proteins showed changes as compared with the control plant proteins, where new and missed protein bands were detected nearly at each detergent concentration. The changes in protein patterns, the molecular weights, and the numbers of proteins, in the roots and shoots which resulted under the stress of the detergent, may prevent the normal protein formation, suppressing some, and changing the enzymatic activities. All these changes could be the explanation to the changes observed on the growth of tomato plants. In most cases, the enhancement effect associated with the lowest concentration, and the inhibitory effect associated with the higher concentrations, on seed germination, seedling length, root and shoot dry weights, survival of plants, chlorophylls and carotene contents, may be due to the changes that occurred to the patterns of the total soluble proteins. The changes observed in protein patterns may indicate a biochemical alteration at the cellular level of the tested crop plants. Helenius and Simons (1975) reported that surfactants reacted with essential proteins necessary to the functioning of the cell. Also, Helleston (1986) mentioned that surfactants cause the break-up of the chlorophyll-protein complex and death of the cell by damaging the membrane.

The change in the protein pattern in plant cells due to LAS products(detergents)application, directs to the importance of such study on the Animals cells and on Human cells.

This is very important, and may be limiting, when planning for National industrial developing projects in Egypt.

\section{REFERENCES}

Abo El-Saad, M. and Wu, R. 1995. A rice membrane cadmium- dependent protein kinase is induced by gibberellins. Plant Physiol. 108: 787-793.

Arnon, D. 1949. Copper enzymes in isolated chloroplasts polyphenoloxidases in Beta vulgaris. Plant Physiology 24: 1-15 (Cited after Bhowmik and Drohen, 2001).

Bhowmik, P. C. and Drohen, J. A. 2001. Differential response of cool-season turfgrass species to isoxaflutole. International Turfgrass Society, Research Journal 9: 1-8.

Cairns, R. R. 1972. Effects of surfactants applied to samples of Solonetz on water penetration and plant growth. Can. J. Soil Sci. 52: 267-269.

Chiming, Y., Jenchieh, H., Yihkuang, L. and Minghorng, Y. 1996. Pigment solubilization of the chloroplast thylakoid membranes by a surfactant. Botanical Bulletin of Academia Sinica 37 (2): 121-126.

Deleu, M. and Paquot, M. 2004. From renewable vegetables resources to microorganisms: new trends in surfactants. C. R. Chimie 7 (2004).

Gadallah, M. A. A. 1994. Effects of industrial and sewage waste waters on the concentration of soluble carbon, nitrogen, and some mineral elements in sunflower plants. Journal of Plant Nutrition 17 (8): 13691384. 
Garland, J. L., Levine, L. H., Yorio, N. C., Adams, J. L. and Cook, K. L. 2000. Graywater processing in recirculating hydroponic systems: phytotoxicity, surfactant degradation, and bacterial dynamics. Water Research 34 (12): 3075-3086.

Helenius, A. and Simons, K. 1975. Solubilization of membranes by detergents. Biochim. Biophys. Acta 415: 29-79 (Abstract).

Helleston, M. 1986. Industrial applications of nonionic surfactants, In industrial applications of surfactants, ed. Karsa, D. R., The Royal Society of Chemistry, London.

Ibrahim, O. G. 1996. Comparative study of detergent and soap marketing in Egypt. International conference and exhibition on soap and detergent technology "Tech So 96 " Organized by ICRC- COMIBASSAL, Alexandria.

Jensen, J. 1999. Fate and effects of linear alkylbenzene sulphonates (LAS) in the terrestrial environment. Science of the Total Environment 226 (2/3): 93-111.

Judy, J. N., Martens, D. C. and Kroontje, W. 1973. Effect of detergent application on the growth of corn. Journal of Environmental Quality 2 (2): 310-314.

Knoche, M., Noga, G. and Lenz, F. 1992. Surfactant-induced phytotoxicity: evidence for interaction with epicuticular wax fine structure. Crop Protection 11(1): 51 - 56.

Kozarac, Z., Bozena, C. and Marko, B. 1975. Spectrophotometric determination of anionic surfactants in sea water. Marine Science Communications 1 (2): 147-163. (Cited after Mahmoud, 1991).

Laemmli, U. K. 1970. Cleavage of structural proteins during the assembly of the head of bacteriophage $T_{4}$. Nature 227: $680-685$.

Lall, S. B. and Kale, C. K. 1975. Response of tomato to a synthetic detergent. Indian Journal of Plant Physiology 18 (1): 46 - 48 (Abstract).

Lian, D. and Shulan, Z. S. 1999. Early stage growth of turfgrasses under increasing stress of linear alkylbenzene sulfonate. Acta Prataculturae Sinica 8 (4): 71 - 76 (Abstract).

Lownds, N. K., Bukovac, M. J. 1989. Surfactant-induced ethylene production by leaf tissue. Journal of the American Society for Horticultural Science 114 (3): 449 - 454.

Lowry, O. H., Rosebrough, N. J., Farr, A. L. and Randall, R. J. 1951. Protein measurement with the Folin phenol reagent. J. Biol. Chem. 193: 265 275 (www.molecularlnfo.com).

Mayfield, S. P., Nelson, T., Tylor, W. C. and Malkin, R. 1986. Carotenoid synthesis and pleiotropic effects in carotenoid-deficient seedlings of maize. Planta 169: 23 - 32.

Mieure, I. P., Waters, J., Holt, M. S. and Matthijs, E. 1990. Terrestrial safety assessment of linear alkylbenzene sulfonate. Chemosphere 21: 251 262.

Nonlinear Dynamics Company, 1998). Totallab Image Analysis Software version 1.11. www.totallab.com. 
Ostroumov, S. A. and Golovko, A. E. 1992. Biotesting of surfactant (sulphonol) toxicity using rice seedlings as a test object. Gidrobiologicheskii Zhurnal 28 (3): 72 - 75 (Abstract).

Patruno, A., Ponzoni, G. and Cavazza, L. 1996. Effect of a surfactant in the irrigation water on the growth of tomato seedlings. Dipartimento di Agronomia, Università degli Studi, Bologna, Italy. Italus Hortus 3 (6): 16 - 22 (Abstract).

SAS Institute. 1988. SAS/STAT user's Guide Release 6.03 Edition. SAS Institute Inc., Cary, NC 27512-8000.1028 pp.

Seier, M., Noga, G. and Lenz, F. 1991. Effect of Triton X-100 surfactant on growth, protein content, ethylene and $\mathrm{CO}_{2}$-production of $P$. vulgaris $\mathrm{L}$. primary leaves. Germany. Angewandte Botanik 65 (1-2): 9 - 22 (Abstract).

Sharma, A. K., Bandre, T. R., Srinivasu, T. and Chandra, N. 1985. Deleterious effects of detergents on plants. Environmental Ecology 3: 444 - 445. (Cited after Jensen, 1999).

Statistical year-Book 2000. Repuplic of Yemen, Ministry of planning and development, Central Statistical Organization , Sanaa, June 2001

Vavrina, C. S., Stansly, P. A. and Liu, T. X. 1995. Household detergent on tomato: Phytotoxicity and toxicity to silverleaf whitefly. Hortiscience 30 (7): $1406-1409$.

Volkering, F., Breure, A. M. and Rulkens, W. H. 1998. Microbiological aspects of surfactant use for biological soil remediation. Biodegradation 8: 401 - 417.

Zavala, L. A., Aluja, A. S., Beatriz, E. L., Manjarrez, L., Buchmann, A., Mercado, L. and Caltenco, S. 1975. The effects of the ABS, LAS and AOS detergents on fish, domestic animals and plants. Prog. Water Technol. 7: 73 - 82 (Cited after Jensen, 1999).

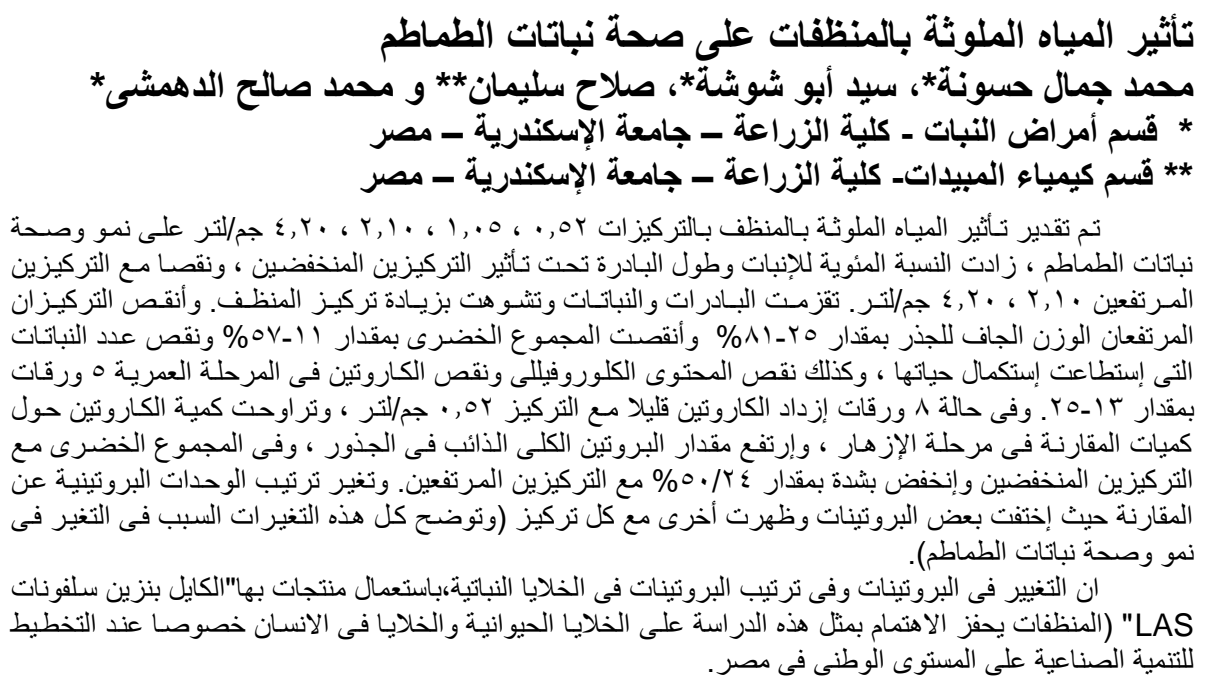

